\title{
Drivers of New Light- Duty Vehicle Fleet Fuel Economy in Saudi Arabia
}

\section{Tamara Sheldon and Rubal Dua}




\section{About KAPSARC}

The King Abdullah Petroleum Studies and Research Center (KAPSARC) is a non-profit global institution dedicated to independent research into energy economics, policy, technology and the environment across all types of energy. KAPSARC's mandate is to advance the understanding of energy challenges and opportunities facing the world today and tomorrow, through unbiased, independent, and high-caliber research for the benefit of society. KAPSARC is located in Riyadh, Saudi Arabia.

\section{Legal Notice}

(C) Copyright 2019 King Abdullah Petroleum Studies and Research Center (KAPSARC). No portion of this document may be reproduced or utilized without the proper attribution to KAPSARC. 


\section{Key Points}

his paper investigates the drivers of recent improvements in the Kingdom of Saudi Arabia's new light-duty vehicle fleet fuel economy. A vehicle choice model is estimated using aggregate and disaggregate new vehicle purchase data. The estimates are used to simulate counterfactual policy scenarios. The simulation results suggest that:

Saudi gasoline price elasticities of fuel economy for new vehicles has been decreasing over recent years, but it is still more elastic than the United States (U.S.) new vehicle market. Given the difference between the Saudi and U.S. new vehicle market responsiveness, pegging Saudi Arabia's fuel economy standards to U.S. fuel economy standards might warrant further economic evaluation.

Figure 1. Estimated gasoline price elasticities of new vehicle fleet fuel economy.

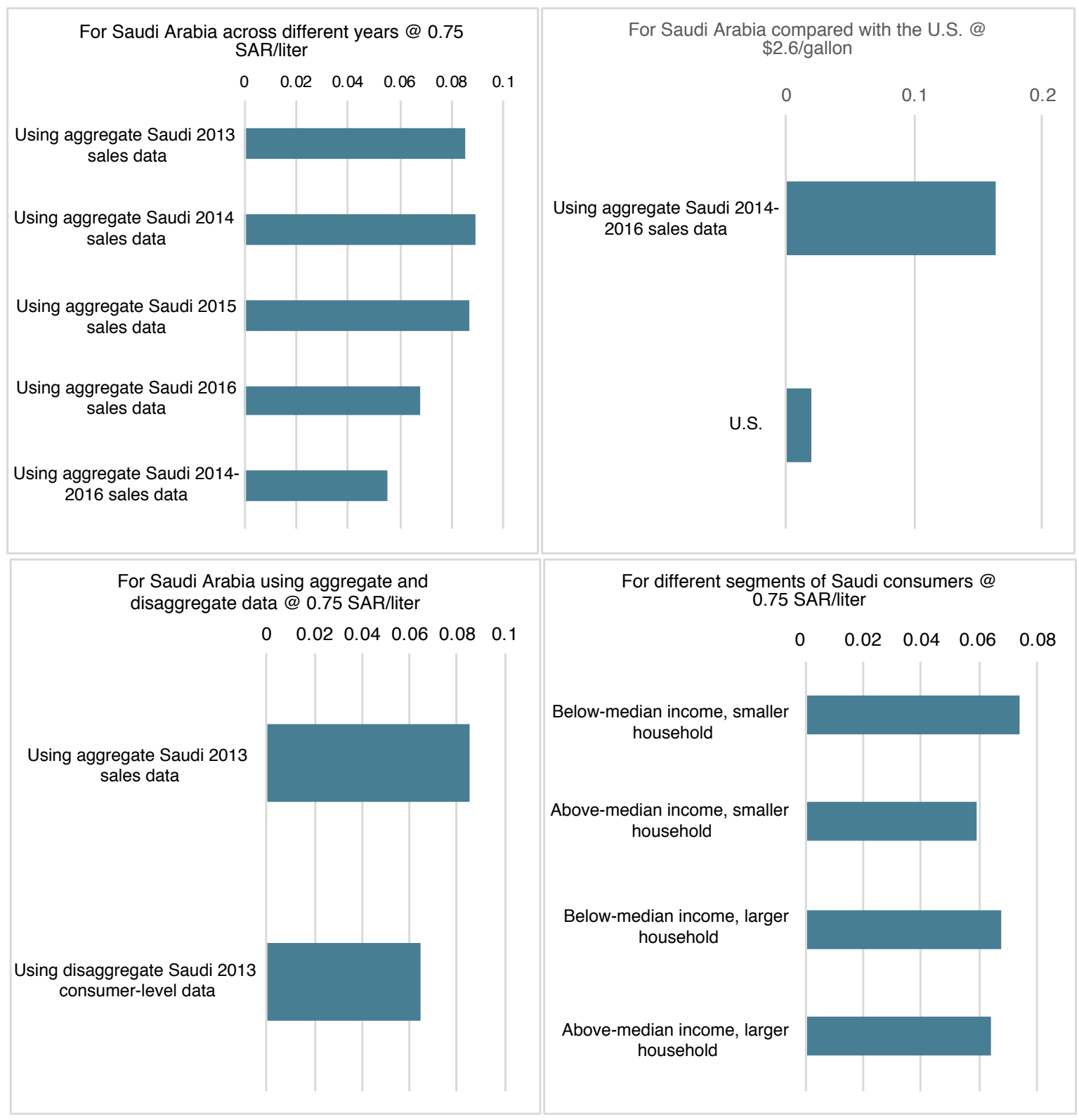




\section{Key Points}

The increase in domestic gasoline prices in Saudi Arabia between 2014 and 2016 accounted for 42\% of the increase in estimated new vehicle fleet fuel economy over that period. The remainder of the increase could be attributable to changes in product offerings and consumer preferences. This was perhaps driven by more cautionary spending given the conservative outlook for Saudi Arabia's economy in that period due to lower international crude oil prices.

The estimated elasticities, and thus policy sensitivities vary by income and household size. Thus, a revenue-neutral 'feebate' policy - involving taxes on fuel-inefficient vehicles and rebates for fuel-efficient vehicles - could be more progressive than a gasoline price increase. 


\section{Summary}

The Kingdom of Saudi Arabia is one of the world's largest consumers of transportation energy, especially on-road motor gasoline. Saudi Arabia is the ninth largest consumer of motor gasoline in the world, despite being only the world's $41^{\text {st }}$ most populous nation. Saudi Arabia has the third highest on-road motor gasoline consumption rate per capita among major motor gasoline markets globally, behind only the United States (U.S.) and Canada.

Factors driving this high level of consumption include the low administered prices of domestic oil products and a lack of alternative transport options. Partly in recognition of this, and to curb domestic oil consumption, Saudi Arabia raised the price of 91 octane gasoline by $20 \%$ in 2015 , by about $67 \%$ in 2016 and by about $80 \%$ in January 2018 . In addition to reductions in gasoline subsidies, the Saudi Standards, Metrology and Quality Organization (SASO) implemented new light-duty vehicle (LDV) (i.e., vehicles with a gross vehicle weight rating of less than 3,500 kilograms) fuel economy standards in January 2016. The standards for new vehicles are based on the U.S. Corporate Average Fuel Economy (CAFE) standards.

This study explores the drivers of new light-duty vehicle fleet fuel economy improvements in Saudi Arabia. In particular, we explore the impact of fuel and vehicle price-related policies on Saudi Arabia's new light-duty vehicle fleet fuel economy. Using both aggregate and disaggregate data on the Kingdom's new vehicle fleet from 2013-2016, a vehicle choice model is estimated and subsequently used to simulate various counterfactual policy scenarios.

Several findings are likely to be of interest to policymakers. First, estimated gasoline price elasticities of fuel economy for new vehicles are significantly larger in Saudi Arabia than in the U.S. This suggests consumer responses to policies similar to those in the U.S. may differ in Saudi Arabia. As such, implementing the U.S. Corporate Average Fuel Economy (CAFE) standards in the Kingdom could have differential impacts on the Saudi economy. Second, estimates suggest that the increase in gasoline prices between 2014 and 2016 accounted for $42 \%$ of the increase in the estimated new vehicle fleet fuel economy over that period, with the remainder of the increase attributable to changing consumer preferences and product offerings with improved fuel economy. This may reflect cautionary consumer spending in the face of lower international crude oil prices from 20142016. Third, simulations showing how costs vary across policies that achieve the same targets may help policymakers improve the cost-effectiveness of current and future policies, such as a vehicle 'feebate' policy (involving taxes on fuel-inefficient vehicles and rebates for fuel-efficient vehicles). Finally, our results show that estimated preferences, elasticities, and thus policy sensitivities vary by income and household size such that a revenueneutral feebate policy could be more progressive than alternative policies. 
audi Arabia is the ninth largest consumer of motor gasoline in the world and the third largest on a per capita basis. The government has implemented several policies in recent years to slow the growth of, or perhaps even reduce, its domestic consumption of oil. Within Saudi Arabia, gasoline is subsidized such that the domestic oil price is lower than the international oil price. The goal of decreased oil consumption could be motivated by the potential welfare gains of increased oil exports: one gallon less consumed domestically is one extra gallon that can be sold on international markets (Blazquez et al. 2018).

In addition to reductions in gasoline subsidies, Saudi Arabia began implementing Corporate Average Fuel Economy (CAFE) standards for new light-duty vehicles in 2016. The government adopted the same standards as the United States (U.S.) 2012
CAFE standards because the Kingdom's vehicle mix and fleet characteristics in 2016 were very similar to those of the U.S. in 2012. Saudi Arabia's CAFE standards lag the U.S. standards by four years and were due to be reviewed in December 2018, after which policymakers were due to set targets for 2021-2025 (ICCT 2014). Saudi Arabia intends to eventually catch up with the U.S. CAFE standards.

This paper explores the drivers of new vehicle fleet fuel economy enhancements in Saudi Arabia - in particular, the impact of fuel and vehicle pricerelated policies on the Kingdom's new vehicle fleet fuel economy. Fuel taxation and vehicle feebates involving tax on fuel-inefficient vehicles and rebate for fuel-efficient vehicles - represent useful policy levers for improving the Kingdom's new-vehicle fleet fuel economy. Previous studies have explored the impact of fuel taxation and feebates for different

Figure 2. On-road motor gasoline consumption per 1,000 people.

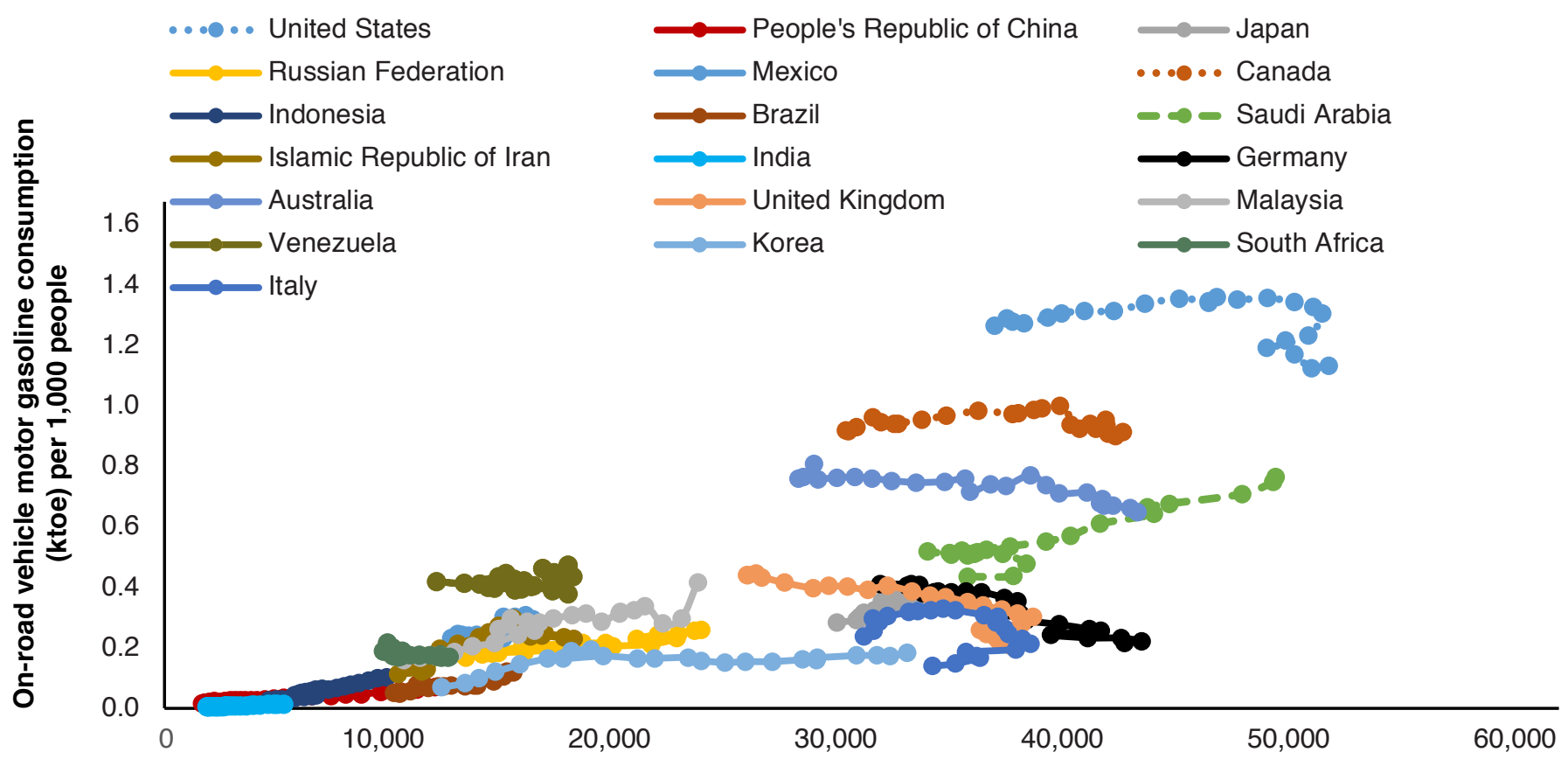

GDP per capita (Purchasing power parity, 2011 international \$)

Source: KAPSARC analysis using World Bank and IEA World Energy Balances data. 
geographies (Li, Timmins, and Von Haefen 2009; Mabit 2014; Giblin and McNabola 2009; Grigolon, Reynaert, and Verboven 2018). This study explores, for the first time, the impact of these policy levers on Saudi Arabia's new light-duty vehicle fleet fuel economy. Such impacts vary with consumer heterogeneity. We also utilize a new vehicle buyer survey data for the Kingdom to explore the variation in policy sensitivity according to income and household size. 
A ggregate market share data for new lightduty vehicles for 2014 to 2016 were obtained from bestsellingcarsblog.com. These include yearly market shares of the top 90 car and light truck makes and models in Saudi Arabia, which account for roughly $95 \%$ of all annual passenger vehicle sales in the Kingdom. These data are merged with Drive Arabia's database of vehicle characteristics to obtain prices, fuel economy, body types, and various performance characteristics.

Table 1 shows summary statistics of the Saudi new vehicle fleet from 2014 to 2016 . The average new vehicle price is around $\$ 26,000$. Unadjusted fleet fuel economy increased from 25.5 miles per gallon (mpg) to $27 \mathrm{mpg}$ over this period. This increase was likely in part due to a decrease in the share of lightduty trucks (from $43 \%$ to $34 \%$ ) and a corresponding increase in the market share of cars. This change in the new light-duty vehicle mix could in turn have been partly due to the increase in the gasoline price from 0.375 Saudi riyals (SAR) per liter (SAR/liter) in 2014 (\$0.38 per gallon [gal]) to $0.75 \mathrm{SAR/liter} \mathrm{in}$ 2016 (\$0.76/gal) and cautionary consumer spending in the face of lower international crude oil prices.

Saudi Arabia's gross domestic product experienced a decline from 2014-2016 (World Bank 2018). In 2016 , the share of advanced clean vehicles, such as hybrid electric vehicles (HEVs), was very small, at only $0.2 \%$.

Individual vehicle transaction data was purchased from Tetrahedron Incorporated. Its New Vehicle Buyer Survey (NVBS) includes a representative sample of new vehicle purchases in the Kingdom for model year 2013. The approximately 7,500 observations account

Table 1. Summary statistics based on aggregate market share of new light-duty vehicles.

\begin{tabular}{|c|c|c|c|c|}
\hline & 2013 & 2014 & 2015 & 2016 \\
\hline Price (\$) & 26,638 & 26,375 & 26,244 & 26,086 \\
\hline $\begin{array}{l}\text { Fleet fuel economy } \\
\text { (mpg, unadjusted) }\end{array}$ & 25.6 & 25.5 & 26.2 & 27.0 \\
\hline $\begin{array}{l}\text { Car fleet fuel economy } \\
\text { (mpg, unadjusted) }\end{array}$ & 30.81 & 31.26 & 31.39 & 31.62 \\
\hline $\begin{array}{l}\text { Truck fleet fuel } \\
\text { economy (mpg, } \\
\text { unadjusted) }\end{array}$ & 20.29 & 20.41 & 20.85 & 21.01 \\
\hline Horsepower & 181 & 183 & 181 & 181 \\
\hline Curb weight (kg) & 1,629 & 1,626 & 1,598 & 1,566 \\
\hline Top speed $(\mathrm{km} / \mathrm{h})$ & 185 & 184 & 186 & 188 \\
\hline Torque (Nm) & 248 & 260 & 256 & 254 \\
\hline Car* $^{*}$ & $61 \%$ & $57 \%$ & $60 \%$ & $66 \%$ \\
\hline Truck $^{\star *}$ & $39 \%$ & $43 \%$ & $40 \%$ & $34 \%$ \\
\hline Hybrid (HEV) & $0.0 \%$ & $0.0 \%$ & $0.0 \%$ & $0.2 \%$ \\
\hline $\begin{array}{l}\text { Gasoline price (SAR/ } \\
\text { liter, 91-grade) }\end{array}$ & 0.375 & 0.375 & 0.45 & 0.75 \\
\hline
\end{tabular}

*A passenger car is any light-duty vehicle (other than a car capable of off-highway operation) manufactured primarily for use in the transportation of no more than 10 individuals (Saudi Standards Metrology and Quality Organization 2014).

${ }^{* *} A$ light truck is any light-duty vehicle that is not a passenger car (Saudi Standards Metrology and Quality Organization 2014).

Source: KAPSARC. 
for $1 \%$ of all new vehicle purchases. These data are also merged with DriveArabia's database of vehicle characteristics. The NVBS also includes individuallevel socio-demographic characteristics.

Table 2 shows summary statistics of the individuallevel data. The analysis divides the sample by income and household size. Above-median income (personal income over $\$ 45,000$ ), smaller household (less than or equal to five persons) consumers comprise $38.3 \%$ of the new car buying population. Below-median income (personal income below $\$ 45,000$ ), smaller household consumers comprise $32.4 \%$ of the new car buying population. Consumers from larger households account for a smaller share of the new car buying population, above-median income consumers for $17.4 \%$ and below-median income consumers for the remaining $11.9 \%$.

Table 2. Summary statistics of individual light vehicle sales for model year 2013

\begin{tabular}{|c|c|c|c|c|}
\hline & $\begin{array}{l}\text { Below-median income } \\
\text { ( }<\$ 5 \mathrm{k}) \text { smaller } \\
\text { household ( }<=5 \\
\text { persons) }\end{array}$ & $\begin{array}{l}\text { Above-median income } \\
\text { ( }>\$ 45) \text { smaller } \\
\text { household ( }<=5 \\
\text { persons) }\end{array}$ & $\begin{array}{l}\text { Below-median } \\
\text { income }(<\$ 45 \mathrm{k}) \text { larger } \\
\text { household ( }>5 \text { persons) }\end{array}$ & $\begin{array}{l}\text { Above-median } \\
\text { income ( }>45 k \text { larger } \\
\text { household ( }>5 \text { persons) }\end{array}$ \\
\hline $\begin{array}{l}\text { Weighted share of } \\
\text { sample }\end{array}$ & $32.4 \%$ & $38.3 \%$ & $11.9 \%$ & $17.4 \%$ \\
\hline Price $(\$)$ & 19,164 & 31,818 & 20,723 & 33,210 \\
\hline $\begin{array}{l}\text { Fleet fuel economy } \\
\text { (mpg, unadjusted) }\end{array}$ & 30.42 & 23.25 & 27.96 & 22.56 \\
\hline Car & $78 \%$ & $54 \%$ & $53 \%$ & $47 \%$ \\
\hline Truck & $22 \%$ & $46 \%$ & $47 \%$ & $53 \%$ \\
\hline
\end{tabular}

Source: KAPSARC. 


\section{Methodology}

A

vehicle choice model is estimated separately for each year of data to account for changing preferences and choice sets (i.e., vehicle availability). For model year 2013, when individual-level data are available, a conditional logit is estimated on the combined choice-set comprising the four incomehousehold size group choice sets; this allows for heterogeneity in preferences. Specifically, a conditional logit is estimated with the utility, $u_{i}$, of a consumer choosing a vehicle of make-model $i$ specified as below in Equation 1.

The utility of choosing a vehicle is thus dependent on the total cost of ownership (price minus resale value plus fuel costs), vehicle characteristics, and a 'popularity' term $S_{i}$, which accounts for spillover effects (Tucker and Zhang 2011). In calculating the resale value and the net present value of fuel costs, a vehicle-holding period of 7.5 years and a real market interest rate of $1 \%$ (Leard, Linn, and
Zhou 2017) are assumed. The vehicle-holding period assumption is based on the average new vehicle holding period calculated using new vehicle experience study data for the U.S. market. The U.S. data assumption was applied to Saudi Arabian consumers, given the lack of such data for the Saudi market. The annual miles per year is assumed to be 16,000 , the average reported mileage for used cars taken from ksa.motory.com. The price of gasoline is assumed to be constant for each year as specified in Table 1. Make-model type dummies are included to account for additional differences in vehicles and to achieve an exact market share match.

Due to the high degree of collinearity between various vehicle attributes in revealed preference data, choice models estimated using utility functions that are linear in attributes often result in estimated parameters that are of the unexpected sign (Earnhart 2002; Haaf 2014). To address multicollinearity issues, all vehicle attributes enter

\section{Equation 1.}

$$
u_{i}=\beta_{g} \frac{\frac{P_{i}-R V_{i}+\rho_{F C} F C_{i}}{\left(P_{i}-R V_{i}+F C_{i}\right)_{\text {avg }}}}{\rho_{H P} \frac{H P_{i}}{H P_{\text {avg }}}+\rho_{C W} \frac{C W_{i}}{C W_{\text {avg }}}+\rho_{T S} \frac{T S_{i}}{T S_{\text {avg }}}+\rho_{\text {Tor }} \frac{\text { Tor }_{i}}{\text { Tor }_{\text {avg }}}+\rho_{S} \ln \left(\frac{S}{S_{\text {avg }}}\right)} d_{g}+\text { make }- \text { model }_{i} \gamma_{1}+\varepsilon_{i}
$$

where:

$P_{i}$ : Price

$R V_{i}$ : Net present value of resale price

$F C_{i}$ : Net present value of fuel costs

$H P_{i}$ : Horsepower

$S_{i}$ : Previous year sales

$C W_{i}$ : Curb weight

$T S_{i}$ : Top speed

Tor $_{i}:$ Torque

$\rho_{x}$ : Weights for respective vehicle characteristics

$d_{g}$ : Group-specific dummy for disaggregate consumer-level data

make - model $_{i}$ : Vector of make-model indicators. 
the utility function in a combined attribute variable, and preference parameters are estimated using an iterative, constrained optimization. The numerator is a linear combination of attributes with a negative expected sign (price and fuel costs), and the denominator is a linear combination of attributes with a positive expected sign (performance characteristics and popularity), such that $\beta_{g}$ has a negative expected sign. Attributes are normalized by dividing by average values to avoid issues of scale.

There are two estimation stages. In the first, iterative stage, a conditional logit model is estimated excluding the make-model indicators and assuming initial values of $\rho$ greater than zero. One of the $\rho$ values is changed by a small delta amount (with $\rho$ always greater than zero) and the conditional logit is estimated again. If the change results in a lower Akaike information criterion (AIC) and Bayesian information criterion (BIC), the updated parameter value is used; otherwise, the previous parameter value is used. The set of $\rho$ values is iteratively updated, and the process is repeated until no meaningful change in $\mathrm{AIC/BIC}$ is observed. In the second stage, a conditional logit is estimated on the entire utility function (including make-model indicators) with $\beta_{g}$ and the set of $\rho$ 's constrained to the values solved for in the first stage. 


\section{Results}

$\mathrm{T}$ The estimated coefficients are used to calculate the elasticity of the new vehicle fleet fuel economy with respect to changes in the price of gasoline. Table 3 shows the estimated elasticities. It assumes a gasoline price of 0.75 Saudi riyal (SAR)/liter ( $\$ 0.76$ per gallon). The elasticity remained almost constant from 2013 to 2015 at $~ 0.087$, then decreased to 0.068 in 2016, suggesting a reduction in the Kingdom's consumer gasoline price sensitivity in recent years. Total new vehicle sales in the Kingdom also declined by about 20\% in 2016 (focus2move 2017), perhaps partly driven by the increase in the domestic gasoline price in 2016 among other factors, including cautionary consumer spending. It is likely that the most pricesensitive consumers left the new car market, either entering the used car market or holding on to their current car longer, thereby resulting in a decrease in the elasticity of the remaining new vehicle buyer population. This is supported by the fact that below-median income households are more price sensitive than above-median income households, as observed using the disaggregated 2013 consumer-level data. Within the below-median income group, the elasticity of smaller households is somewhat larger than that of larger households. This may be because of the higher market share of smaller, more fuel-efficient cars in smaller belowmedian income households, as shown in Table 2. As a result, smaller households in the below-median income group are more responsive to changes in the gasoline price. For the above-median income group, larger households are somewhat more elastic than smaller households. The financial constraints on the budget as a result of larger family sizes could potentially explain the larger-sized household group's somewhat higher elasticity than the smaller sized household group within the above-median income category.

Although fuel price sensitivity decreased in 2016, Saudi consumers are more price-responsive than

Table 3. Estimated gasoline price elasticities of new vehicle fleet fuel economy

\begin{tabular}{l|l|l|l|l} 
Year & Gasoline price & Data type & Elasticity \\
\hline 2014 & 0.75 SAR/liter & Using aggregate Saudi 2014 sales data & 0.089 \\
\hline 2015 & 0.75 SAR/liter & Using aggregate Saudi 2015 sales data & 0.087 \\
\hline 2016 & 0.75 SAR/liter & Using aggregate Saudi 2016 sales data & 0.068 \\
\hline $2014-2016$ combined & 0.75 SAR/liter & Using aggregate Saudi 2014-2016 sales data & 0.055 \\
\hline $2014-2016$ combined & $\$ 2.6 /$ gallon & Using aggregate Saudi 2014-2016 sales data & 0.163 \\
\hline $1997-2005$ & $\$ 2.6 /$ gallon & U.S. & $0.019^{*}$ \\
\hline 2013 & 0.75 SAR/liter & Using aggregate Saudi 2013 sales data & 0.085 \\
\hline 2013 & 0.75 SAR/liter & Using disaggregate Saudi 2013 consumer-level data & 0.065 \\
\hline 2013 & 0.75 SAR/liter & Below-median income, smaller household & 0.074 \\
\hline 2013 & 0.75 SAR/liter & Above-median income, smaller household & 0.059 \\
\hline 2013 & 0.75 SAR/liter & Below-median income, larger household & 0.068 \\
\hline
\end{tabular}

\footnotetext{
* From Li, Timmins, and Von Haefen (2009)
}

Source: KAPSARC. 
U.S. consumers. For example, using the choice model estimates based on the combined 2014-2016 data, and assuming a higher gasoline price of $\$ 2.6$ per gallon, results in an elasticity of 0.163 . This is an order of magnitude greater than the short-run elasticity estimate of 0.019 for new vehicles in the U.S. found by Li, Timmins, and Von Haefen (2009), which also assumes a gasoline price of $\$ 2.6 /$ gal. The greater price sensitivity of the Kingdom's consumers relative to U.S. consumers suggests pegging Saudi fuel economy standards to the U.S. CAFE standards may have differential impacts on the Saudi economy, warranting further economic analysis.

The relatively larger elasticity suggests that an increase in the gasoline price will have bigger impacts on new vehicle fleet fuel economy in the Kingdom than in the U.S. Indeed, as Table 1 shows, when the gasoline price doubled from 0.375 SAR/liter in 2014 to 0.75 SAR/liter in 2016, fuel economy of the Saudi new vehicle fleet increased from $25.5 \mathrm{mpg}$ to $27 \mathrm{mpg}$. However, this improvement in new vehicle fleet fuel economy could also be due to changes in consumer preferences (e.g., increasing popularity of clean vehicles or smaller vehicles) that are independent from the increase in the gasoline price. Furthermore, the product offerings in the new vehicle market change from year to year and the average fuel economy of available vehicles may increase due to global trends. To disentangle these effects, the fleet fuel economy is predicted holding a constant choice set and preference and changing only the gasoline price. Using the parameter estimates based on the combined 2014-2016 data and the 2014 vehicle offerings, the fleet fuel economy is predicted using the 2014 gasoline price and compared to the fleet fuel economy predicted using the $\mathbf{2 0 1 6}$ gasoline price. The difference in the two predictions shows that $42 \%$ of the increase in the fleet fuel economy from 2014 to 2016 was directly attributable to the increase in the gasoline price, with the remaining
$58 \%$ due to changes in preferences and/or product offerings. This suggests that the gasoline price is an important, but not the only, driver of fleet composition and fuel economy. In the period under analysis, i.e., 2014-2016, Saudi consumers may have been more cautious in their overall spending, given the country's economic outlook in the face of lower international crude oil prices.

The estimated choice model is used to predict the Saudi new vehicle fleet under different counterfactual policy scenarios. Each scenario is designed to result in a similar percentage increase in new vehicle fleet fuel economy $(\sim 3.5 \%$, roughly similar to the desired improvement in fleet fuel economy in CAFE) and hence similar annual gasoline savings (approximately $3.4 \%$ ). The results are based on the 2016 vehicle offerings and choice model estimates, based on the combined 20142016 data. Table 4 compares these counterfactual policies in terms of percentage change in new car fuel economy, new truck fuel economy, the percentage change in car market share, and net annual revenues. In Scenario 1, the gasoline price increases from 0.45 SAR/liter to 1.21 SAR/liter. Scenario 2 is a revenue-negative feebate policy, while Scenarios 3 and 4 are revenue-neutral feebate policies.

The feebate policy in Scenario 2 uses a rate of $\$ 1,980$ per $\$ 0.01 \mathrm{gal} / \mathrm{mile}(\sim \$ 156 / \mathrm{mpg})$, pivoted around the actual 2016 fleet fuel economy value. To achieve revenue neutrality, the feebate policy in Scenario 3 uses a fee rate of $\$ 2,260$ per $\$ 0.01 \mathrm{gal} /$ mile and a rebate rate of $\$ 1,738$ per $\$ 0.01 \mathrm{gal} / \mathrm{mile}$. Scenario 4 is similar to Scenario 3, but it assigns different feebate schedules to cars and trucks pivoted around their fleet fuel economy values. The fee rates for cars and trucks is $\$ 5,385$ and $\$ 5,725$ per $\$ 0.01 \mathrm{gal} / \mathrm{mile}$, respectively. The rebate rate for cars and trucks is $\$ 3,971$ and $\$ 3,135$ per $\$ 0.01$ gal/ 


\section{Results}

Table 4. Comparison of policy counterfactuals

\begin{tabular}{|c|c|c|c|c|}
\hline & $\begin{array}{l}\text { Counterfactual } \\
\text { Scenario 1: increase } \\
\text { gasoline price to } 1.21 \\
\text { SAR/liter from } 0.75 \\
\text { SAR/liter }\end{array}$ & $\begin{array}{l}\text { Counterfactual } \\
\text { Scenario } 2 \text { : } \\
\text { gasoline price of } \\
0.75 \text { SAR/liter \& } \\
\text { feebate }\end{array}$ & $\begin{array}{l}\text { Counterfactual } \\
\text { Scenario 3: gasoline } \\
\text { price of } 0.75 \text { SAR/liter } \\
\& \text { revenue neutral } \\
\text { feebate }\end{array}$ & $\begin{array}{l}\text { Counterfactual Scenario } \\
4: \text { gasoline price of } 0.75 \\
\text { SAR/liter \& revenue neutral } \\
\text { feebate; separate feebate } \\
\text { for cars and trucks }\end{array}$ \\
\hline $\begin{array}{l}\text { Change in new } \\
\text { vehicle fleet fuel } \\
\text { economy }\end{array}$ & $3.57 \%$ & $3.54 \%$ & $3.54 \%$ & $3.57 \%$ \\
\hline $\begin{array}{l}\text { Annual gasoline } \\
\text { savings }\end{array}$ & $3.45 \%$ & $3.42 \%$ & $3.42 \%$ & $3.45 \%$ \\
\hline $\begin{array}{l}\text { Change in new car } \\
\text { fuel economy }\end{array}$ & $2.96 \%$ & $1.60 \%$ & $1.49 \%$ & $3.32 \%$ \\
\hline $\begin{array}{l}\text { Change in new truck } \\
\text { fuel economy }\end{array}$ & $1.48 \%$ & $1.29 \%$ & $1.45 \%$ & $3.41 \%$ \\
\hline $\begin{array}{l}\text { Change in car } \\
\text { market share }\end{array}$ & $4.27 \%$ & $7.04 \%$ & $7.02 \%$ & $0.72 \%$ \\
\hline $\begin{array}{l}\text { Net annual revenue, } \\
\text { where saved gallon } \\
\text { is exported (million } \\
\text { dollar) }\end{array}$ & $\$ 304$ & $-\$ 135$ & $-\$ 0.01$ & $\$ 0.05$ \\
\hline $\begin{array}{l}\text { Average fee } \\
\text { (\% of MSRP) }\end{array}$ & & $\begin{array}{l}\$ 1,920 \\
(5.3 \%)\end{array}$ & $\begin{array}{l}\$ 2,177 \\
(6.0 \%)\end{array}$ & $\begin{array}{l}\text { Car: } \$ 2,475 \\
\text { Truck: } \$ 3,764\end{array}$ \\
\hline $\begin{array}{l}\text { Average rebate } \\
\text { (\% of MSRP) }\end{array}$ & & $\$ 1,492(9.5 \%)$ & $\begin{array}{l}\$ 1,304 \\
(8.3 \%)\end{array}$ & $\begin{array}{l}\text { Car: } \$ 1,439 \\
\text { Truck: } \$ 2,380\end{array}$ \\
\hline
\end{tabular}

Source: KAPSARC.

mile, respectively. Finally, underpinning the analysis, are four key assumptions: 1) annual vehicle miles traveled (VMT) remain the same, 2) the total number of vehicles sold remains the same as in 2016,3) one barrel of oil produces 30 gallons of gasoline, and 4) a crude oil price of $\$ 75$ per barrel (Paraskova 2018).

Scenario 1 illustrates the fleet fuel economy improvements and gasoline savings attributable to a further increase in the gasoline price (from $0.45 \mathrm{SAR} /$ iter to $1.21 \mathrm{SAR} /$ liter). Higher gasoline prices not only induce consumers to purchase both more fuel-efficient cars and trucks but also induce would-be truck buyers to purchase cars instead. The car market share is $4.27 \%$ higher in Scenario 1 than in the baseline (no policy). This policy results in a $3.57 \%$ improvement in new fleet fuel economy and an annual gasoline saving of $3.45 \%$. If the gasoline saved by this policy were exported to global markets, it would generate annual revenues of $\$ 304$ million.

Scenario 2 illustrates how a feebate policy could achieve similar policy goals as an alternative to raising domestic gasoline prices. Charging fees to consumers who purchase relatively fuel-inefficient vehicles and giving rebates to those who purchase relatively fuel-efficient vehicles results in a similar improvement in new fleet fuel economy (3.54\%) and annual gasoline savings (3.42\%) as in Scenario 1. 
This policy also results in a larger increase in car market share (7.04\%) than in Scenario 1. Since consumers who purchase more fuel-efficient vehicles receive rebates from the government, net annual revenue in Scenario 2 is $-\$ 135$ million (i.e., a net cost).

Scenario 3 shows a feebate policy with similar metrics to Scenario 2's, except that it is designed to be revenue neutral. That is, rather than raising government revenues as in Scenario 1 and increased spending as in Scenario 2, in Scenario 3 , vehicle prices are distorted via the feebate policy in such a way as to redistribute dollars from consumers purchasing fuel-inefficient vehicles and increased 'saved-oil' exports to those purchasing fuel-efficient vehicles. To achieve this revenue neutrality, the average fee is slightly higher $(\$ 2,177$ versus $\$ 1,920)$ and the average rebate slightly lower $(\$ 1,304$ versus $\$ 1,492)$ in

\section{Scenario 3 versus Scenario 2.}

In Scenarios 1, 2, and 3, many of the increases in fuel economy and gasoline savings are due to a shift in the vehicle mix from trucks to cars. Scenario 4 illustrates a feebate policy that would achieve similar new fleet fuel economy and annual gasoline savings goals while avoiding a substantial shift in the vehicle mix. That is, Scenario 4 would adjust incentives to allow consumers to purchase a car or truck as they would have chosen absent the policy. Table 4 shows that Scenario 4 achieves a similar improvement in new fleet fuel economy (3.57\%) and annual gasoline savings (3.45\%) as achieved in Scenarios 1, 2, and 3. However, Scenario 4 achieves these at greater average fee and rebate values. Averaged over the entire fleet, including cars and trucks, the average fee for Scenario 4 is $\$ 2,394$ compared to $\$ 2,177$ for Scenario 3; while average rebate for Scenario 4 is

Table 5. Comparison of feebate Scenario 5 simulated using the choice model based on 2013 consumer-level data.

\begin{tabular}{|c|c|c|c|c|c|}
\hline $\begin{array}{l}\text { Counterfactual Scenario } 5: \\
\text { gasoline Price of } 0.375 \text { SAR/ } \\
\text { liter \& revenue neutral feebate }\end{array}$ & $\begin{array}{l}\text { All groups } \\
\text { combined }\end{array}$ & $\begin{array}{l}\text { Below-median } \\
\text { income, smaller } \\
\text { household }\end{array}$ & $\begin{array}{l}\text { Above-median } \\
\text { income, smaller } \\
\text { household }\end{array}$ & $\begin{array}{l}\text { Below-median } \\
\text { income, larger } \\
\text { household }\end{array}$ & $\begin{array}{l}\text { Above-median } \\
\text { income, larger } \\
\text { household }\end{array}$ \\
\hline $\begin{array}{l}\text { Change in new fleet fuel } \\
\text { economy }\end{array}$ & $3.59 \%$ & $3.64 \%$ & $3.51 \%$ & $3.73 \%$ & $3.65 \%$ \\
\hline Annual gasoline savings & $3.47 \%$ & $3.51 \%$ & $3.39 \%$ & $3.59 \%$ & $3.52 \%$ \\
\hline Change in new car fuel economy & $1.57 \%$ & $1.71 \%$ & $1.43 \%$ & 1. $74 \%$ & $1.48 \%$ \\
\hline $\begin{array}{l}\text { Change in new truck fuel } \\
\text { economy }\end{array}$ & $0.45 \%$ & $1.06 \%$ & $1.14 \%$ & $1.11 \%$ & $1.18 \%$ \\
\hline Change in car market share & $9.33 \%$ & $8.91 \%$ & $9.55 \%$ & $9.25 \%$ & $9.99 \%$ \\
\hline $\begin{array}{l}\text { Net annual revenue, where } \\
\text { saved gallon is exported } \\
\text { (millions) }\end{array}$ & $\$ 0.06$ & $-\$ 241$ & $\$ 230$ & $-\$ 95$ & $\$ 106$ \\
\hline Average fee ( $\%$ of MSRP) & $\begin{array}{l}\$ 2,979 \\
(7.2 \%)\end{array}$ & $\begin{array}{l}\$ 1,260 \\
(4.7 \%)\end{array}$ & $\begin{array}{l}\$ 3,391 \\
(8.1 \%)\end{array}$ & $\begin{array}{l}\$ 1,041 \\
(3.9 \%)\end{array}$ & $\begin{array}{l}\$ 3,377 \\
(8.2 \%)\end{array}$ \\
\hline Average rebate (\% of MSRP) & $\begin{array}{l}\$ 1,886 \\
(11.6 \%)\end{array}$ & $\begin{array}{l}\$ 1,992 \\
(12.6 \%)\end{array}$ & $\begin{array}{l}\$ 1,734 \\
(10.3 \%)\end{array}$ & $\begin{array}{l}\$ 2,057 \\
(13.1 \%)\end{array}$ & $\begin{array}{l}\$ 1,730 \\
(10.3 \%)\end{array}$ \\
\hline
\end{tabular}

Source: KAPSARC. 


\section{$\$ 1,774$ versus $\$ 1,304$ for Scenario 3 .}

Table 5 shows the results for a counterfactual revenue-neutral feebate policy simulated using the choice model based on 2013 disaggregate consumer-level data. To achieve revenue neutrality and similar improvements in fleet fuel economy, the feebate policy in Scenario 5 uses a fee rate of $\$ 1,880$ per $\$ 0.01 \mathrm{gal} / \mathrm{mile}$ and a rebate rate of $\$ 1,496 \mathrm{per} \$ 0.01 \mathrm{gal} / \mathrm{mile}$ pivoted around the actual 2013 fleet fuel economy value.

Scenario 5 illustrates that similar policy goals to the other scenarios could be achieved by a progressive feebate policy design, where higher rebates and lower fees are levied on below-median income consumers compared to above-median income consumers. The below-median income consumers receive a total of $\$ 347$ million in subsidies to purchase fuel-efficient vehicles while above-median income consumers together pay \$318 million in fees for purchasing fuel-inefficient vehicles. This is because the fleet fuel economy for each group is different from the 2013 fleet fuel economy chosen as the pivot point for the feebate policy. Below-median income consumer groups have higher fleet fuel economy compared to the 2013 fleet average and thus receive more rebates. On the other hand, above-median income groups have lower fleet fuel economy than the 2013 fleet average and thus end up accumulating more fees. As a result, while the overall policy is still revenue-neutral, it favors the below-median income consumers through much lower average fees $(\$ 1,041-\$ 1,260)$ compared to above-median income consumers $(\$ 3,377-\$ 3,391)$. The average rebate fees for below-median income consumers $(\$ 1,992-\$ 2,057)$ are also slightly higher compared to above-median income consumers $(\$ 1,730$ $\$ 1,734)$. Similar progressive subsidy designs for clean vehicle-related policies have also been recently reported in the literature (Sheldon and Dua 2018; DeShazo, Sheldon, and Carson 2017). These designs are currently under either pilot stage testing (CARB 2015) and/or fully implemented (CVRP 2016). 


\section{Conclusion}

audi Arabia has recently increased the domestic price of gasoline and implemented

CAFE standards in an effort to reduce domestic oil consumption. Using both aggregate and disaggregate new light-duty vehicle transaction data from 2013-2016, this paper estimates consumer choice models to investigate the drivers of the Kingdom's new light-duty vehicle fleet fuel economy. First, estimates suggest that although new vehicle buyers in the Kingdom have become less price responsive to increases in gasoline prices in recent years, they are still more price sensitive than U.S. consumers. This may have implications for implementing U.S. CAFE standards in Saudi Arabia. Second, results suggest the increase in gasoline prices between 2014 and 2016 accounted for $42 \%$ of the increase in the estimated new lightduty vehicle fleet fuel economy over that period, with the remainder of the increase attributable to changing consumer preferences and product offerings. This may reflect cautionary consumer spending in the face of lower international crude oil prices during the period 2014-2016 of the analysis. Finally, policy simulations show that additional new light-duty vehicle fleet fuel economy improvements could be achieved using either a further increase in the gasoline price or a feebate policy. Given the estimated heterogeneity in consumer preferences and price elasticities of demand, a revenue-neutral feebate policy could be more progressive than alternative simulated policies. 


\section{References}

Blazquez, Jorge, Baltasar Manzano, Lester C. Hunt, and Axel Pierru. 2018. "The value of saving oil in Saudi Arabia." KAPSARC discussion paper. https://doi: 10.30573/KS--2018-DP030

California Air Resources Board (CARB). 2015. "Car Scrap and Replace." https://www.arb.ca.gov/msprog/lct/ vehiclescrap.htm

Clean Vehicle Rebate Project (CVRP). 2016. "Increased lower-income incentives and reduced high-income caps start Nov. 1, 2016." Center for Sustainable Energy, San Diego, California. https://energycenter.org/article/ california-clean-vehicle-rebate-project-initiates-neweligibility-requirements

DeShazo, J. R., Tamara L. Sheldon, and Richard T. Carson. 2017. "Designing policy incentives for cleaner technologies: Lessons from California's plug-in electric vehicle rebate program." Journal of Environmental Economics and Management 84: 18-43. https://doi. org/10.1016/j.jeem.2017.01.002

Earnhart, Dietrich. 2002. "Combining revealed and stated data to examine housing decisions using discrete choice analysis." Journal of Urban Economics 51 (1): 143-169. https://doi.org/10.1006/juec.2001.2241

Focus2move. 2017. "Saudi Arabia 2016. The deepest fall in 20 years." February 11. https://focus2move.com/ saudi-arabia-vehicles-sales-2016/

Giblin, Sean, and Aonghus McNabola. 2009. "Modelling the impacts of a carbon emission-differentiated vehicle tax system on $\mathrm{CO} 2$ emissions intensity from new vehicle purchases in Ireland." Energy Policy 37 (4): 1404-1411. https://doi.org/10.1016/j.enpol.2008.11.047

Grigolon, Laura, Mathias Reynaert, and Frank Verboven. 2018. "Consumer Valuation of Fuel Costs and Tax Policy: Evidence from the European Car Market." American Economic Journal: Economic Policy 10 (3): 193-225. https://doi: 10.1257/pol.20160078

Haaf, Christine Grace. 2014. "Vehicle Demand Forecasting with Discrete Choice Models: 2 Logit 2 Quit." Ph.D. diss., Carnegie Mellon University.
The International Council on Clean Transportation (ICCT). 2014. "Proposed Saudi Arabia Corporate Average Fuel Economy Standard for New Light-Duty Vehicles (2016-2020)." Policy Update, December. https://www.theicct.org/sites/default/files/publications/ ICCTupdate_KSA-CAFE-proposal_20141218.pdf

Leard, Benjamin, Joshua Linn, and Yichen Christy Zhou. 2017. "How much do consumers value fuel economy and performance." Evidence from technology adoption. Washington, DC: Resources for the Future.

Li, Shanjun, Christopher Timmins and Roger H. Con Haefen. 2009. "How do gasoline prices affect fleet fuel economy?" American Economic Journal: Economic Policy, 1(2): 113-37. https://doi.org/10.1257/pol.1.2.113

Mabit, Stefan L. 2014. "Vehicle type choice under the influence of a tax reform and rising fuel prices." Transportation Research Part A: Policy and Practice, 64: 32-42. https://doi.org/10.1016/j.tra.2014.03.004

Paraskova, Tsvetana. 2018 "Saudi Arabia's Oil Price Sweet Spot." OilPrice.com, September 5. https://oilprice. com/Energy/Oil-Prices/Saudi-Arabias-Oil-Price-SweetSpot.html

Saudi Standards Metrology and Quality Organization. (2014). "Saudi Arabia Corporate Average Fuel Economy Standard (Saudi CAFE) For Incoming Light Duty Vehicles (2016-2020)." http://www.saso.gov.sa/ar/standards/ Documents/KR-2422.doc

Sheldon, Tamara L., and Rubal Dua. 2018. "Measuring the Cost-effectiveness of Clean Vehicle Subsidies." KAPSARC discussion paper. https://doi.org/10.30573/ ks--2018-dp033

Tucker, Catherine, and Juanjuan Zhang. 2011. "How does popularity information affect choices? A field experiment." Management Science 57 (5 ): 828-842. https://doi. org/10.1287/mnsc.1110.1312

The World Bank. 2018 "World Bank GDP Data for Saudi Arabia 2018." https://data.worldbank.org/indicator/ NY.GDP.MKTP.CD?locations=SA 


\section{About the Authors}

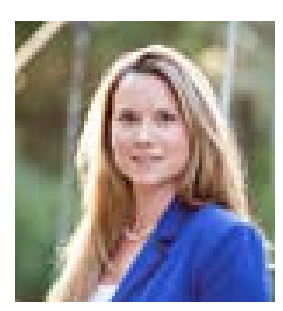

\section{Tamara Sheldon}

Tamara is a visiting researcher at KAPSARC and an assistant professor of economics in the Darla Moore School of Business at the University of South Carolina. Her research interests include environmental and energy economics and how these fields interact with public policy. She holds a Ph.D. in Economics from the University of California, San Diego.

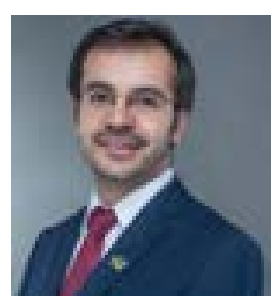

\section{Rubal Dua}

Rubal is a research fellow at KAPSARC, working on vehicle regulatory policy and shared mobility research from the consumer perspective. He holds a Ph.D. from KAUST, Saudi Arabia, an M.Sc. from the University of Pennsylvania, and a B.Tech. from the Indian Institute of Technology, Roorkee.

\section{About the Project}

Promoting the adoption of energy-efficient vehicles has become a key policy imperative in both developed and developing countries. Understanding the impact of various factors that affect adoption rates forms the backbone of KAPSARC's efforts in the light-duty vehicle demand field. These include (i) consumer-related factors - demographics, behavioral, and psychographics; (ii) regulatory factors - policies, incentives, rebates, and perks; and (iii) geo-temporal factors - weather, infrastructure, and network effects. Our team is currently developing models at different levels: micro-level models using large-scale data comprising new car buyers' profiles, and macro-level models using aggregated adoption data to understand and project the effects of various factors that affect the adoption rate of energyefficient vehicles. 
INAPSARC

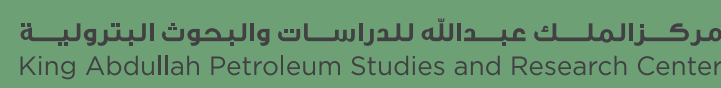

www.kapsarc.org 